Jurnal Akses Pengabdian Indonesia Vol 3 No 1:1-6, 2018

\title{
IbM UKM Kerupuk Ikan Di Desa Pangkah Wetan Kecamatan UjungPangkah Kabupaten Gresik Jawa Timur
}

\author{
Azimmatul Ihwah ${ }^{1}$, Danang Triagus Setiyawan ${ }^{2}$ \\ ${ }^{1,2}$ Jurusan Teknologi Industri Pertanian, Fakultas Teknologi Pertanian, Universitas Brawijaya \\ e-mail: azimmatul.ihwah@gmail.com
}

\begin{abstract}
Abstrak
Kecamatan Ujung Pangkah Kabupaten Gresik Jawa Timur. Kerupuk yang diproduksi oleh mayoritas pengrajin adalah dalam bentuk 'mentah'. Bahan baku pembuatan kerupuk berupa ikan sangat melimpah di desa ini dan sebagian besar masyarakatnya bermata pencaharian sebagai nelayan. Ikan yang digunakan untuk bahan baku pembuatan kerupuk adalah ikan payus, laosan dan pahat.Terdapat sekitar 10 keluarga pengrajin kerupuk ikan di Desa Pangkah Wetan yang aktif berproduksi. Kendala yang dihadapi saat ini adalah dalam proses produksi. Alat untuk melakukan proses produksi semuanya masih manual sehingga berdampak pula pada jam kerja yang tidak efektif serta hasil produksi yang dihasilkan tidak maksimal.Kemasan kerupuk dapat dikatakan kurang menarik. Pengemasnya berupa kantong plastik ukuran $0.5 \mathrm{~kg}$, kemudian ditutup dengan staples atau karet gelang, tanpa ada informasi sama sekali mengenai berat bersih maupun komposisi bahan. Teknologi yang diintroduksi kepada pengrajin melalui fasilitasi alat berupa mesin pencampur adonan kerupuk, mesin pencetak adonan kerupuk lontongan, mesin pemotong adonan lontongan dan hand sealer (pengemas) memenuhi syarat LLM (Low Technology, Low Investment dan Markettable). Dilaksanakan pelatihan perbaikan bentuk produk serta kemasan produk dengan memberikan materi pentingnya kemasan yang baik dan informasi apa saja yang harus tercantum pada kemasan produk. Monitoring, evaluasi dilakukan secara internal dan eksternal untuk memantau kekonsistenan dan kendala pemakaian alat produksi yang telah ditransfer ke UKM mitra.
\end{abstract}

Kata Kunci: kerupuk ikan; mesin pencampur; mesin pencetak; mesin pemotong; pelatihan

\section{PENDAHULUAN}

Desa Pangkah Wetan merupakan salah satu sentra pengrajin kerupuk berbahan dasar ikan di Kecamatan Ujung Pangkah Kabupaten Gresik Jawa Timur. Kerupuk yang diproduksi oleh mayoritas pengrajin adalah dalam bentuk 'mentah'. Bahan baku pembuatan kerupuk berupa ikan sangat melimpah di desa ini dan sebagian besar masyarakatnya bermata pencaharian sebagai nelayan. Ikan yang digunakan untuk bahan baku pembuatan kerupuk adalah ikan payus, laosan dan pahat. Sebagian besar, hasil produksinya dijual di rumah mereka sendiri dengan menunggu konsumen datang untuk membeli ataupun dibeli kerabat sendiri untuk oleh-oleh. Pengrajin mengalami kesulitan pendistribusian karena untuk pendistribusian ke luar kota, produk mereka masih kalah bersaing dengan yang ada di kota-kota besar. Jika diamati kemungkinan ada beberapa hal yang mempengaruhi hal tersebut terjadi, yaitu dikarenakan produk kerupuk yang mereka produksi dikemas dalam kemasan yang kurang menarik, tidak ada informasi mengenai produk seperti berat bersih dan komposisi bahan, serta seringkali dalam satu kemasan bentuk kerupuk tidak sama besar. Hollensen (2003) 
menyebutkan bahwa ada 4 atribut produk yang mempengaruhi pertimbangan konsumen dalam membeli produk, salah satunya adalah atribut kinerja yang meliputi ketahanan, kualitas material, konstruksi, ketergantungan, kinerja fungsi.

Dari 10 pengrajin aktif, belum ada pengrajin yang memiliki izin PIRT (Pangan Industri Rumah Tangga) dari Dinas Kesehatan (Dinkes). Namun, kendala yang dihadapi oleh pengrajin disini rata-rata sama. Kendala yang dihadapi saat ini adalah dalam proses produksi. Padahal proses produksi ini sangat mempengaruhi produk yang dihasilkan. Alat produksi yang digunakan pengrajin dalam melakukan proses produksi semuanya masih manual.Dari segi ukuran kerupuk pun cenderung tidak konsisten karena dalam mencetak adonan berbentuk silinder (lontongan) hanya menggunakan tangan sedangkan untuk mengiris adonan silinder (lontongan) yang telah dikukus masih manual. Alat produksi yang masih manual ini berdampak pula pada jam kerja yang tidak efektif serta hasil produksi yang dihasilkan tidak maksimal.

Hampir seluruh pengrajin mengemas kerupuk yang siap dipasarkan dalam kemasan yang kurang menarik. Yang dikatakan kurang menarik disini adalah pengemasnya berupa kantong plastik ukuran $1 \mathrm{~kg}$, kemudian ditutup dengan staples atau karet gelang, tanpa ada informasi sama sekali mengenai berat bersih ataupun komposisi produk

Beberapa situasi yang dialami pengrajin kerupuk di Desa Pangkah Wetan tersebut diatas menjadi penyebab bahwa mereka membutuhkan pelatihan dan pendampingan mengenai cara pengadonan dan pencetakan kerupuk, penyeragaman kuantitas, teknologi kemasan dan pelabelan.Teknologi yang akan diintroduksi kepada pengrajin dengan tujuan perbaikan bentuk produk, kuantitas dan pengemasan kerupuk melalaui fasilitasi alat berupa mesin pencampur adonan kerupuk, mesin pencetak adonan kerupuk silinder, mesin pemotong adonan silinder yang telah dikukus dan hand sealer (pengemas) yang memenuhi syarat LLM (Low Technology, Low Investment dan Markettable) akan dapat mudah diadopsi oleh pengrajin.

\section{METODE KEGIATAN}

Metode pendekatan penyelesaian kendala yang dihadapi UKM mitra adalah dengan meningkatkan kapasitas produksi dan mempersingkat waktu produksi serta memperbaiki kemasan produk melalui introduksi alat produksi dan pelatihan Prosedur penyelesaian masalah yang dilakukan antara lain:

1. Melakukan survei mengenai kebutuhan alat produksi serta mendata alat produksi apa saja yang telah mereka miliki.

2. Memberikan informasi mengenai teknis pelaksanaan kegiatan pengabdian masyarakat yang akan dilakukan.

3. Melakukan pelatihan perbaikan bentuk produk kerupuk dan kemasan yang agar seragam dan informatif.

4. Melakukan evaluasi terhadap kegiatan pelatihan.

5. Melakukan monitoring dan pendampingan kepada UKM mitra mengenai konsistensi dan kendala yang dihadapi dalam penggunaan alat produksi yang telah diintroduksi.

\section{III.HASIL DAN PEMBAHASAN}

Sebelum introduksi alat produksi ke UKM mitra, Ketua dan Anggota pelaksanaan kegiatan pengabdian masyarakat melakukan kunjungan ke mitra UKM Kerupuk Ikan di Gresik untuk melakukan survei, koordinasi dan 
sosialisasi kegiatan pengabdian masyarakat yang akan dilakukan. Kegiatan dilakukan selama 2 hari mengingat ada 2 UKM yang akan dikunjungi dan jarak yang ditempuh dari Malang sejauh $141 \mathrm{~km}$.
Dalam kegiatan kunjungan tersebut, pelaksana kegiatan memberikan penjelasan kegiatan pengabdian yang akan dilakukan dan menanyakan lebih lanjut permasalahan mitra yang sudah diketahui sebelumnya.

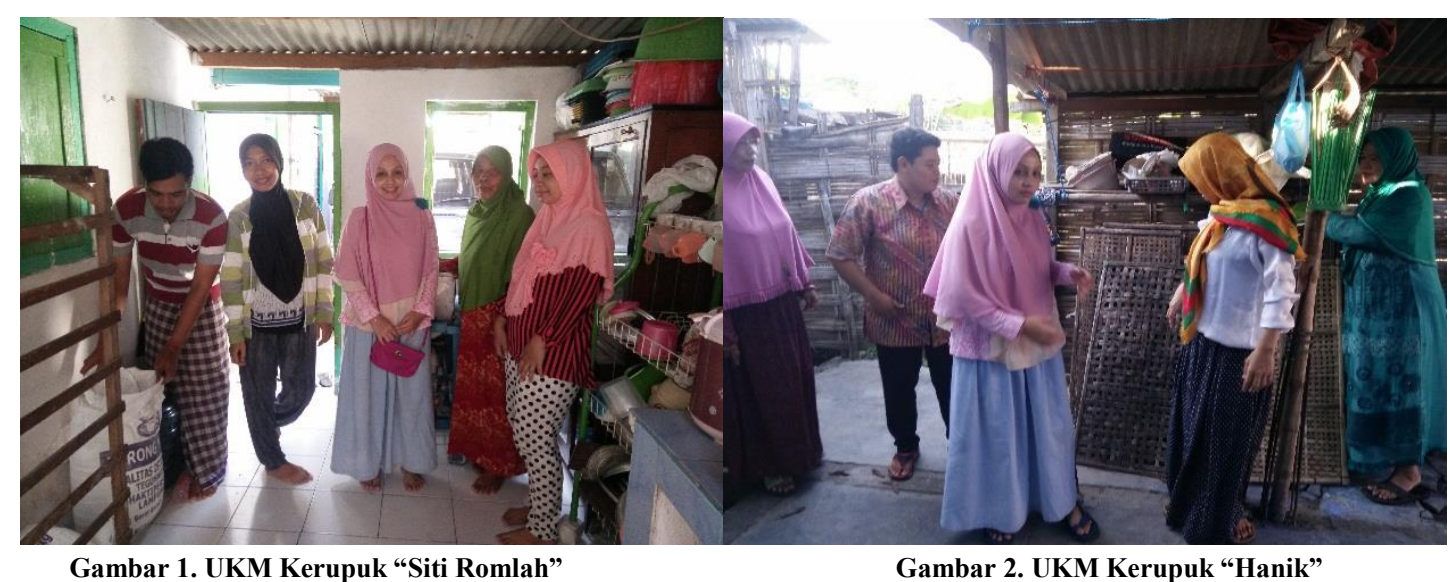

Gambar 1. UKM Kerupuk "Siti Romlah"

Gambar 2. UKM Kerupuk "Hanik"

Selanjutnya pelaksana kegiatan pengabdian masyarakat melakukan pemesanan alat produksi berdasarkan informasi pada survei sebelumnya. Setelah alat produksi jadi dan siap dikirim, pengiriman menggunakan mobil bak terbuka dari Malang menuju Gresik. Alat diterima langsung oleh pemilik UKM, yaitu Ibu Hanik (Gambar 3) dan Ibu Siti Romlah (Gambar 4).

Kegiatan pelatihan bentuk dan kemasan produk kerupuk dilakukan selama satu hari penuh. Sebelum peserta diberikan materi dan penjelasan mengenai manfaat dan definisi kemasan produk yang baik, peserta diminta mengerjakan soal pre-test. Setelah pelatihan dilakukan, peserta diminta kembali untuk mengerjakan soal post-test dan mengisi kuisioner materi pelatihan. Untuk pretest dan postest yang diberikan ditampilkan dalam grafik berikut ini. Dari grafik menunjukkan peserta mengalami kenaikan nilai setelah dilakukan pelatihan, nilai menjawab benar semakin banyak.Dari 6 peserta pelatihan, nampak bahwa setelah diberikan materi mengenai fungsi dan manfaat kemasan serta strategi pemasaran adalah rata-rata peserta pelatihan mengalami kenaikan skor (Gambar 6)

\section{DAMPAK DAN MANFAAT}

Setelah pelatihan dilakukan, peserta diminta untuk mengisi kuisioner sebagai survey kepuasan peserta. Hasilnya ditunjukkan pada diagram lingkaran sebagai berikut (Gambar 7). 


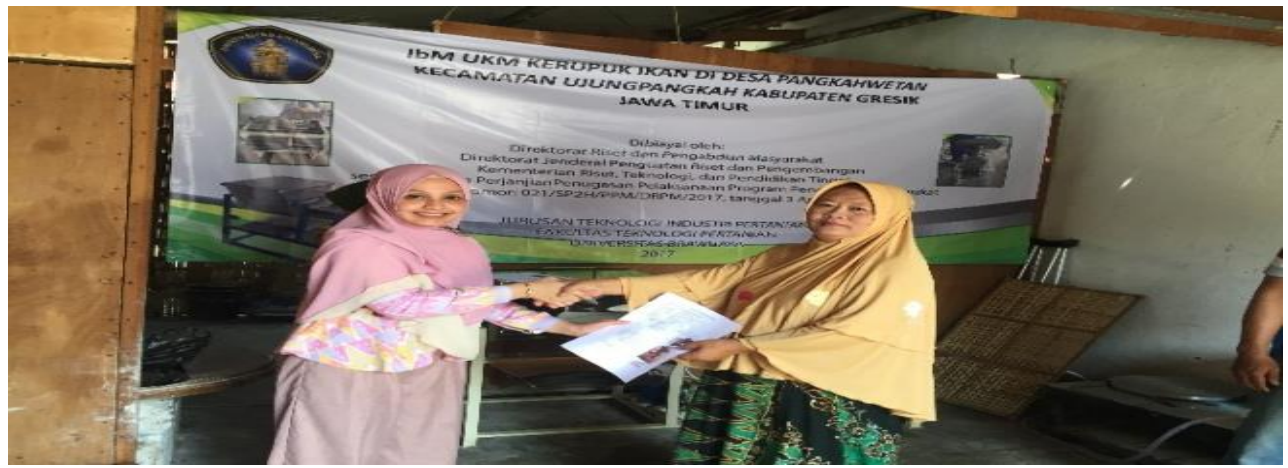

Gambar 3. Serah Terima Alat Produksi dengan UKM Kerupuk "Hanik"

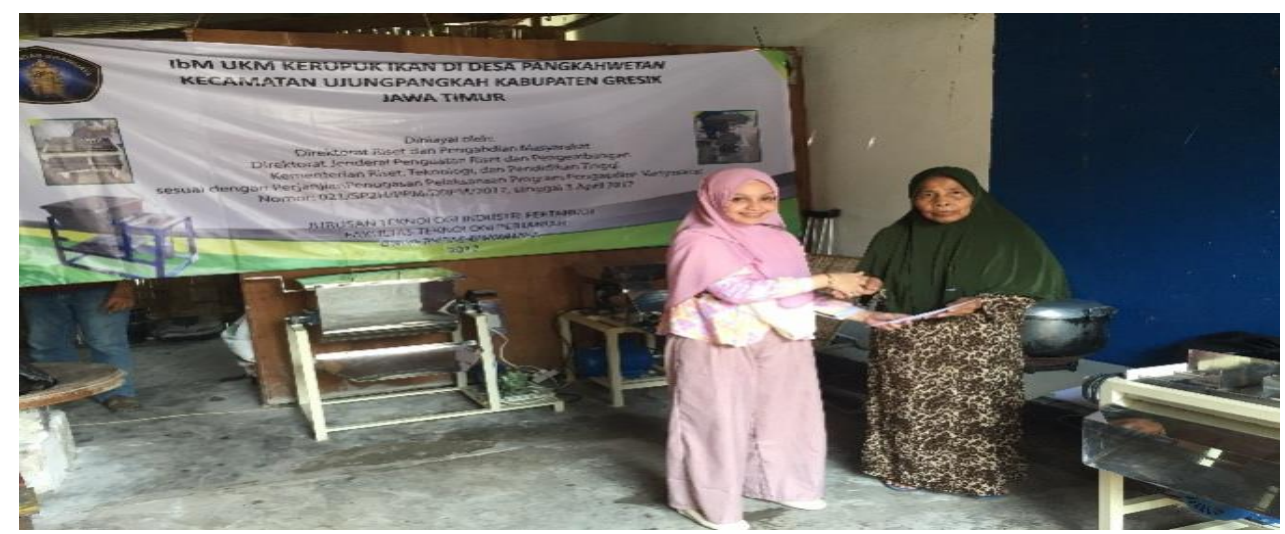

Gambar 4. Serah Terima Alat Produksi dengan UKM Kerupuk "Siti Romlah"

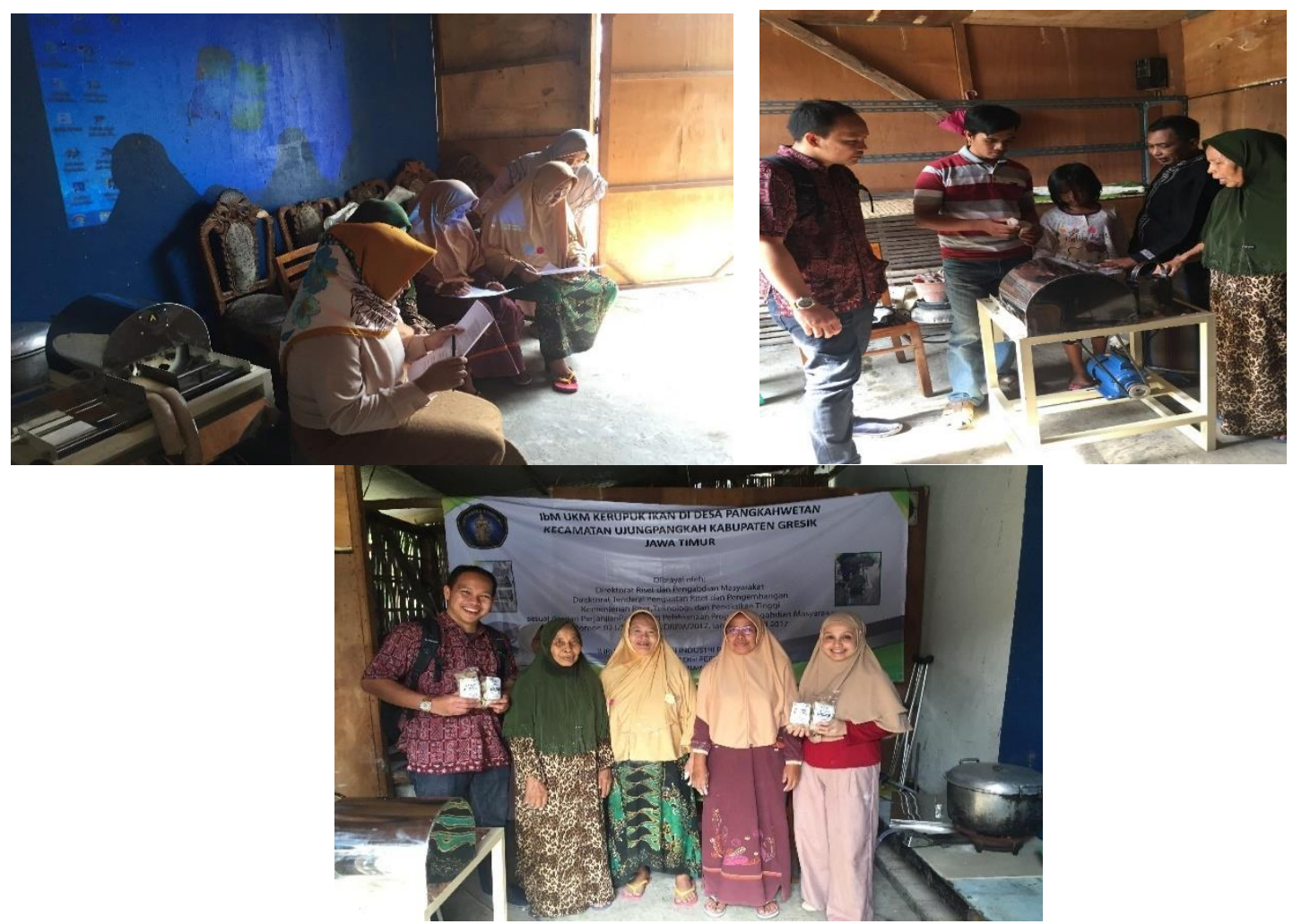




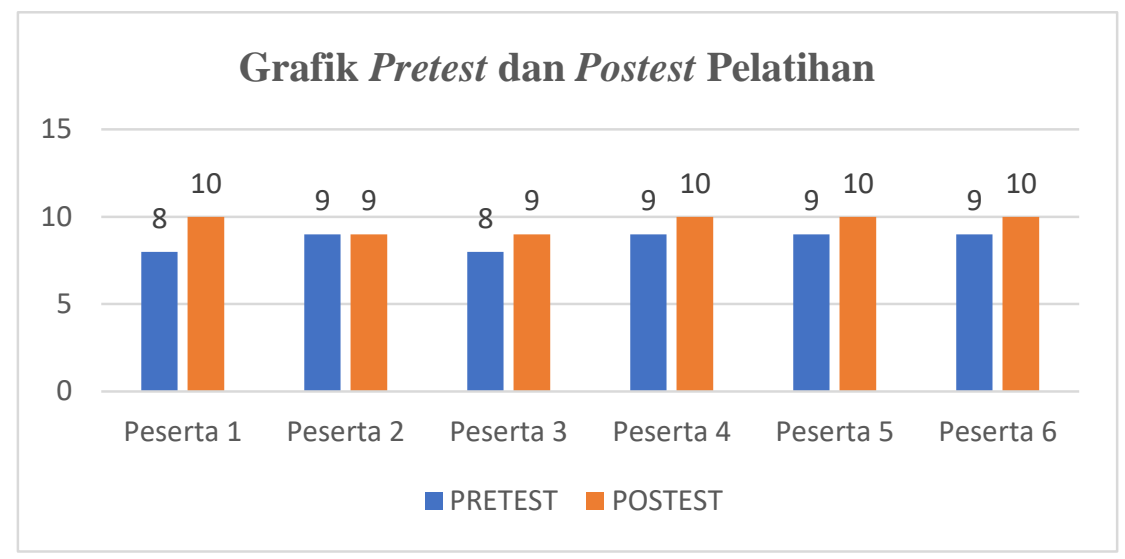

Gambar 6. Hasil Pre-test dan Post-test Pelatihan Perbaikan Bentuk

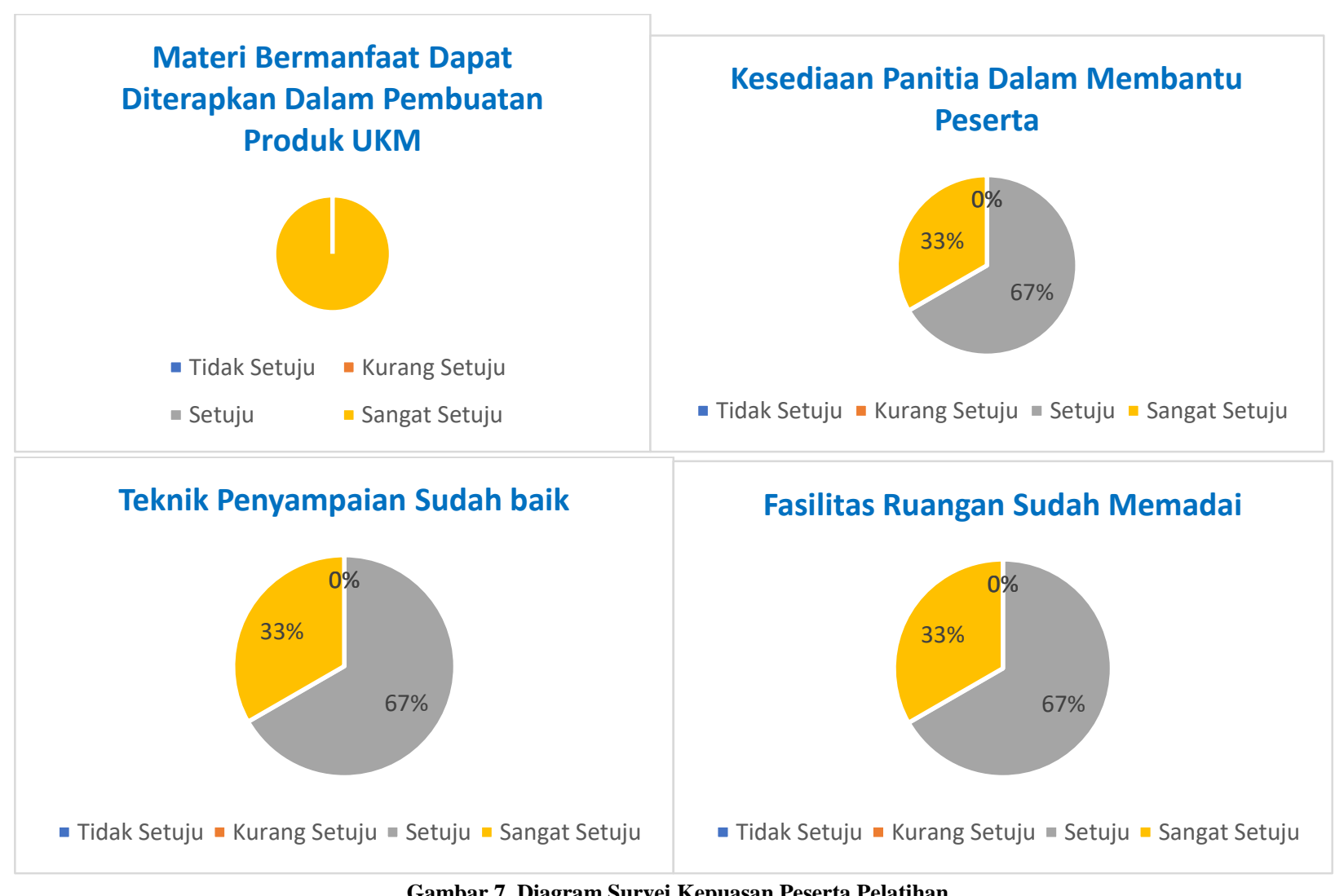

Gambar 7. Diagram Survei Kepuasan Peserta Pelatihan

\section{KESIMPULAN DAN SARAN}

Dari kegiatan pengabdian masyarakat yang telah dilakukan, terdapat beberapa kesimpulan:

1 Dalam mendeteksi kendala yang dialami UKM mitra, motode survei dan wawancara sangat efektif sekali.
2 Materi pelatihan dapat disesuaikan dengan kebutuhan serta tingkat pendidikan peserta pelatihan yang merupakan pekerja di UKM mitra.

3 Mengevaluasi dan memonitoring setiap kegiatan pengabdian masyarakat yang dilakukan, sehingga menjadi tahu apakah 
masih terdapat kendala yang dihadapi UKM mitra.

4 Dari hasil kuisioner pelatihan yang telah diisi oleh peserta, mayoritas peserta merasa puas dengan materi, fasilitas serta teknik penyampaian pelatihan.

Saran dari pelaksanaan kegiatan pengabdian masyarakat ini adalah kendala yang masih dihadapi oleh UKM mitra hendaknya diperhatikan untuk dijadikan bahan kajian pelaksanaan pengabdian masyarakat selanjutnya, serta pihak pelaksana pengabdian masyarakat dapat terus secara kontinyu melakukan evaluasi dan monitoring terhadap keberlanjutan penggunaan alat yang sudah diintroduksi dan ditransfer ke UKM mitra.

\section{DAFTAR PUSTAKA}

Balai Besar Kimia dan Kemasan. Peraturan Kemasan dan Pedoman Umum Pelabelan. BBKK. Kementrian Perindustrian Republik Indonesia. Jakarta,2014.

Hollensen , S. Marketing Management-A Relationship Approach, Upper Saddle River'. New Jersey: Prentice Hall, 2003 